\title{
Chemical and structural characterization of exopolymers produced by Pseudomonas sp. NCIMB 2021 in continuous culture
}

\author{
Iwona Beech, ${ }^{2}$ Likit Hanjagsit, ${ }^{2}$ Maher Kalaji, ${ }^{1}$ Andy L. Neal ${ }^{1}$ \\ and Vitaly Zinkevich ${ }^{2}$
}

Author for correspondence: Maher Kalaji. Tel: +441248382516 . Fax: +441248383741.
e-mail: m.kalaji(a bangor.ac.uk

1 Department of Chemistry, University of Wales/Bangor, Bangor LL57 2UW, UK

2 School of Pharmacy and Biomedical Sciences, University of Portsmouth, St Michael's Building, White Swan Road, Portsmouth P01 2DT, UK

\begin{abstract}
The growth of marine Pseudomonas sp. NCIMB 2021 as continuous cultures in the presence of surfaces of AISI 316 stainless steel allowed the isolation and partial chemical characterization of exopolymers released into the culture medium (free exopolymers), as well as capsular and biofilm exopolymers. Fourier-transform infrared (FTIR) spectroscopy demonstrated the presence of $\boldsymbol{O}$ - and $\boldsymbol{N}$-acetylation within the carbohydrate moieties and a predominant $3_{10}$-helical structure of the protein component, highly resistant to hydrogen/deuterium exchange. Differences between the exopolymers were apparent. Relatively less uronic acid residues were detected in the capsular exopolymers compared to either the biofilm or free exopolymers. $\mathrm{O}$ - and $\mathrm{N}$ acetylation were greatest in the biofilm exopolymer. SDS-PAGE protein profiles confirmed differences between exopolymers. The secondary structures of proteins determined using FTIR spectroscopy indicated that the capsular exopolymer had reduced helical content and an increased aggregated strand content compared to the biofilm exopolymer. However, the free exopolymer had an increased $\beta$-sheet component and a reduced unordered component when compared to the biofilm and capsular exopolymers. These data suggest that exopolymer chemistry varies with cellular mode of growth.
\end{abstract}

Keywords: Pseudomonas sp. NCIMB 2021, extracellular polymeric substances, capsule, biofilm, FTIR

\section{INTRODUCTION}

Bacteria produce a wide range of extracellular polymeric substances (EPS) composed of polysaccharides, proteins, nucleic acids and lipids. EPS are often classified as capsules, sheaths or slimes dependent upon their proximity or attachment to the cell wall (Beveridge \& Graham, 1991). Such classifications take no regard of the chemistry of the EPS, despite the fact that they may have markedly different functions. A polymer responsible for irreversible cell adhesion to a surface is likely to contrast with EPS which forms a protective gel-like matrix around attached cells, and the respective structures may reflect these differences (Allison \& Sutherland, 1987; Neu \& Marshall, 1991; Allison et al., 1991).

Abbreviations: EPS, extracellular polymeric substances; FTIR, Fouriertransform infrared.
It is becoming clear that planktonic (suspended) and biofilm (sessile) bacterial cells may be phenotypically distinct (Dagostino et al., 1991; Davies et al., 1993; Hoyle et al., 1993; Vandevivere \& Kirchman, 1993). The change upon adhesion to surfaces is precipitated by a $\sigma$-factor acting to derepress inactive genes (Deretic et al., 1994; Martin et al., 1994). Phenotypic differences in Pseudomonas aeruginosa are particularly evident, with the up-regulation of alginate production following adhesion (Davies et al., 1993; Hoyle et al., 1993). In any system with sufficient nutrients for bacterial growth, biofilms will predominate (Geesey et al., 1978), with all the attendant advantages and disadvantages to man. It is therefore important to understand the biochemical transformation that cells undergo following adhesion since assumptions based upon planktonic cells may be misleading.

Whilst the chemical characterization of EPS is not novel, the exopolymers in question are invariably either 
released into the culture medium ('free' exopolymer), or associated with cells attached to a substratum (e.g. Williams \& Wimpenny, 1977; Christensen et al., 1985; Abu et al., 1991; Robijn et al., 1995). During a programme of research investigating the influence of the biofilm formed by marine Pseudomonas sp. NCIMB 2021 on the deterioration of AISI 316 stainless steel and the possible role of exopolymers in this process, the use of a continuous-flow bioreactor, with a large surface area potentially available for colonization $\left(1600 \mathrm{~cm}^{2}\right)$, allowed the study of the three types of EPS produced: capsular exopolymers, those constituting the biofilm matrix (biofilm) and those released into the culture medium (free). Here we report on the chemical and structural differences between the three types as established by SDS-PAGE protein profiles and Fouriertransform infrared (FTIR) spectroscopy.

\section{METHODS}

Organism. A strain of the marine isolate Pseudomonas sp. NCIMB 2021 was grown and maintained as batch cultures at $25^{\circ} \mathrm{C}$ in an artificial seawater-based laboratory-designed medium $\left(\mathrm{l}^{-1}: 1.54 \mathrm{~g} \mathrm{CaCl}_{2}, 11.1 \mathrm{~g} \mathrm{MgCl}_{2}, 24.53 \mathrm{~g} \mathrm{NaCl}, 0.1 \mathrm{~g}\right.$ $\mathrm{KBr}, 0.017 \mathrm{~g} \mathrm{SrCl}_{2}, 0.003 \mathrm{~g} \mathrm{NaF}, 0.7 \mathrm{~g} \mathrm{KCl}, 0.03 \mathrm{~g} \mathrm{H}_{3} \mathrm{BO}_{3}$, $4.09 \mathrm{~g} \mathrm{Na}_{2} \mathrm{SO}_{4}$ and $0.2 \mathrm{~g} \mathrm{NaHCO}_{3}$ in double-distilled water) containing $\left(\mathrm{l}^{-1}\right): 2 \mathrm{~g}$ tryptone, $2 \mathrm{~g}$ Casamino acids, $0 \cdot 1 \mathrm{~g}$ glucose and $2 \mathrm{ml}$ vitamin solution $\left(1^{-1}: 0.5 \mathrm{mg}\right.$ nicotinic acid, $0.6 \mathrm{mg} \mathrm{B}_{1}, 0.05 \mathrm{mg} \mathrm{B}_{12}, 0.2 \mathrm{mg} \mathrm{B}_{2}, 0.6 \mathrm{mg} \mathrm{B}_{5}, 0.6 \mathrm{mg} \mathrm{B}_{6}, 2 \mathrm{mg}$ $\mathrm{C}$ and $0.001 \mathrm{mg} \mathrm{H}$ ) and $1 \mathrm{ml}$ trace element solution $[1.5 \mathrm{~g}$ nitrilotriacetic acid $\mathrm{l}^{-1}$, adjusted to $\mathrm{pH} 6.5$ with $1 \mathrm{M} \mathrm{KOH}$, plus $\left(\mathrm{l}^{-1}\right): 3 \mathrm{~g} \mathrm{MgSO}_{4}, 0 \cdot 5 \mathrm{~g} \mathrm{MnSO}_{4}, 1 \mathrm{~g} \mathrm{NaCl}, 0 \cdot 1 \mathrm{~g} \mathrm{FeSO}_{4}$, $0 \cdot 1 \mathrm{~g} \mathrm{CoSO}_{4}, 0 \cdot 1 \mathrm{~g} \mathrm{NiCl}_{2}, 0 \cdot 1 \mathrm{~g} \mathrm{CuCl}_{2}, 0 \cdot 1 \mathrm{~g} \mathrm{ZnSO}_{4}, 0 \cdot 01 \mathrm{~g}$ $\mathrm{CuSO}_{4}, 0.01 \mathrm{~g} \mathrm{AlK}\left(\mathrm{SO}_{4}\right)_{2}, 0.01 \mathrm{~g} \mathrm{H}_{3} \mathrm{BO}_{3}, 0.01 \mathrm{~g} \mathrm{Na}_{2} \mathrm{MoO}_{4}$ and $0.001 \mathrm{~g} \mathrm{Na}_{2} \mathrm{SeO}_{3}$, adjusted to $\mathrm{pH} 6 \cdot 5-7 \cdot 0$, filter-sterilized $\left(0.2 \mu \mathrm{m}\right.$ pore size filters; Millipore) and stored at $\left.4{ }^{\circ} \mathrm{C}\right]$. A $4.5 \mathrm{l}$ continuous-flow bioreactor was designed to study exopolymer production by Pseudomonas sp. NCIMB 2021 in the presence of AISI 316 cold-rolled 1600 grade stainless steel surfaces (Rightons). The computer-controlled bioreactor accommodated a sterile air purger, temperature probe and $\mathrm{pH}$ and $\mathrm{O}$, electrodes. Sterile stainless steel coupons (total area $1600 \mathrm{~cm}^{2}$ ) were aseptically introduced into the bioreactor and held vertically in PTFE holders. The bioreactor was run supplied with sterile growth medium $\left(1 \mathrm{ml} \mathrm{min}^{-1}\right)$ for $24 \mathrm{~h}$ in order to confirm the maintenance of sterile conditions, after which it was inoculated with $40 \mathrm{ml}$ of a 5 -d-old batch culture of Pseudomonas sp. NCIMB 2021 grown as described above. A magnetic propeller provided slow agitation of the medium and sterile air was supplied via an in-line $0.2 \mu \mathrm{m}$ membrane filter (Millipore).

Recovery of EPS. After $36 \mathrm{~d}$ operation, the bulk phase was removed from the bioreactor and the planktonic cells harvested using centrifugation $\left(10000 \mathrm{~g}\right.$ for $\left.30 \mathrm{~min}, 4^{\circ} \mathrm{C}\right)$. The resultant supernatant was dialysed for $24 \mathrm{~h}$ against running tap water using $10 \mathrm{kDa}$ molecular mass cut-off dialysis membrane (Fisher Scientific) at $4^{\circ} \mathrm{C}$, followed by $48 \mathrm{~h}$ extensive dialysis against double-distilled water, again at $4{ }^{\circ} \mathrm{C}$. The exopolymers (termed 'free' EPS) were lyophilized at $-60^{\circ} \mathrm{C}$ and stored at $-20^{\circ} \mathrm{C}$. The cells removed by centrifugation from the bulk phase were gently suspended in $200 \mathrm{ml}$ isotonic TE buffer $(10 \mathrm{mM}$ Tris $/ \mathrm{HCl} \mathrm{pH} 8,10 \mathrm{mM}$ EDTA) containing $2.5 \% \mathrm{NaCl}$ and incubated overnight at $4{ }^{\circ} \mathrm{C}$, after which the cells were removed from the capsular
EPS by centrifugation as described previously. Stainless steel coupons were removed from the bioreactor aseptically and placed in TE buffer as before. Biofilm material was recovered from the coupons by scraping with a sterile, blunt-tipped poly(propylene) automatic pipette tip (Gilson). The biofilm suspension was centrifuged and dialysed as stated above to obtain biofilm EPS.

Partial purification of EPS. To eliminate confusion of carbohydrates associated with polysaccharides from those present in nucleic acids (i.e. ribose and deoxyribose), $6 \mathrm{mg}$ of each lyophilized EPS sample was resuspended in sterile distilled water and incubated for $24 \mathrm{~h}$ at $37^{\circ} \mathrm{C}$ with RNase and DNase (Boehringer Mannheim) at a final enzyme concentration of $20 \mathrm{mg} \mathrm{ml}^{-1}$, buffered with $10 \mathrm{mM} \mathrm{NaCl}, 10 \mathrm{mM}$ Tris $/ \mathrm{HCl} \mathrm{pH}$ 8 . Following digestion, the samples were extensively dialysed against double-distilled water at $4{ }^{\circ} \mathrm{C}$. All samples were lyophilized and stored at $-20^{\circ} \mathrm{C}$ until use.

Characterization of EPS. Colorimetric assays were employed to determine the soluble neutral carbohydrate (Chaplin \& Kennedy, 1986) and protein (Bradford, 1976) contents of the EPS samples.

SDS-PAGE of EPS was performed on $10 \%(\mathrm{w} / \mathrm{v}$ ) acrylamide slab gels with a discontinuous buffer system (Laemmli, 1970). A constant current of $40 \mathrm{~mA}$ was applied until the bromophenol blue tracking dye front reached the bottom of the gel. Low-molecular-mass markers (Bio-Rad) were employed as protein standards. Coomassie brilliant blue R-250 staining procedures were conducted as described by Dzandu et al. (1984).

For FTIR spectroscopy, samples were prepared as $15 \mu \mathrm{g} \mathrm{ml}^{-1}$ solutions in distilled, deionized water (Elgastat UHQ II, 18 $\mathrm{M} \Omega \mathrm{cm}$ resistivity at $25^{\circ} \mathrm{C}$ ). A $7 \cdot 5 \mu \mathrm{l}$ aliquot of each sample was then layered onto the surface of a gold-coated glass slide (1000 $\AA \mathrm{Au}$ over $20 \AA \mathrm{Cr}$ ) with a glass spreader under a stream of dry $\mathrm{N}_{2}$ until a dry film was formed. Prior to sample application, slides were degreased by sonication with Decon 90 〈Decon Laboratory) followed by sonication in concentrated $\mathrm{HNO}_{3}$ and then $5 \mathrm{mM} \mathrm{NaOH}$, resulting in a hydroxyl-rich surface. Measurement of spectra of dried samples layered onto such surfaces has been shown to conserve polymer secondary structure whilst avoiding the problems inherent in studying aqueous solutions (Kossovsky et al., 1994). For the hydrogen/ deuterium (H/D) exchange, samples were dissolved in deuterium oxide $\left(\mathrm{D}_{2} \mathrm{O}>99.9 \%\right.$; Goss Scientific Instruments) for $12 \mathrm{~h}$, lyophilized and the cycle repeated three times.

Single-channel reflectance-absorbance FTIR spectra were obtained at an angle of incidence of $70^{\circ}$ using a Bruker IFS 113v FTIR spectrometer (Bruker) equipped with a narrowrange, liquid- $\mathrm{N}_{2}$-cooled, $\mathrm{Hg}$-Cd-Te (MCT) detector. The spectra were recorded at a resolution of $4 \mathrm{~cm}^{-1}$. The optics chamber, which housed the grazing-angle attachment (Graseby Specac), was evacuated for $3 \mathrm{~h}$ prior to the collection of spectra. This procedure ensured minimal spectral interference from atmospheric $\mathrm{CO}_{2}$ and water vapour. This, coupled with the use of $\mathrm{D}_{2} \mathrm{O}$, enabled a better understanding of the spectral features associated with the amide I band, which would otherwise have been obscured by the absorbance (around wavenumber $1650 \mathrm{~cm}^{-1}$ ) associated with the bending mode of $\mathrm{H}_{2} \mathrm{O}$ (Hernandez \& Kalaji, 1996). A total of 1000 interferograms were averaged for each sample, apodized using a triangular function, zero-filled with a factor of 2 and Fourier-transformed. For curve fitting in the amide I region, derivative spectroscopy [second derivative, 9-point SavitzkyGolay-smoothed (Savitzky \& Golay, 1964)] and Fourier self- 
deconvolution (Rahmelow \& Hübner, 1996) were employed. Curves were fitted using a Levenberg-Marquardt algorithm employing linear combinations of Lorentzian and Gaussian line shapes.

\section{RESULTS}

All samples used for the isolation of EPS material were inspected to determine whether the cells remained intact throughout the procedure. No lysis of cells was observed, indicating a lack of EPS contamination with cellular material. To determine whether cell lysis was taking place, two independent methods were employed. The first approach involved light microscopy observations using total enumeration technique (counting chamber) prior to and following EDTA extraction. There was no significant difference in cell number between treatments, indicating that no bursting or dissolution of cell walls occurred. Following enumeration, aliquots of the samples were deposited on glass and 10 randomly chosen areas on each sample were viewed using atomic force microscopy (AFM), as described by Tapper (1998). No apparent distortions in

$\begin{array}{llllll}1 & 2 & 3 & 4 & \mathrm{kDa}\end{array}$

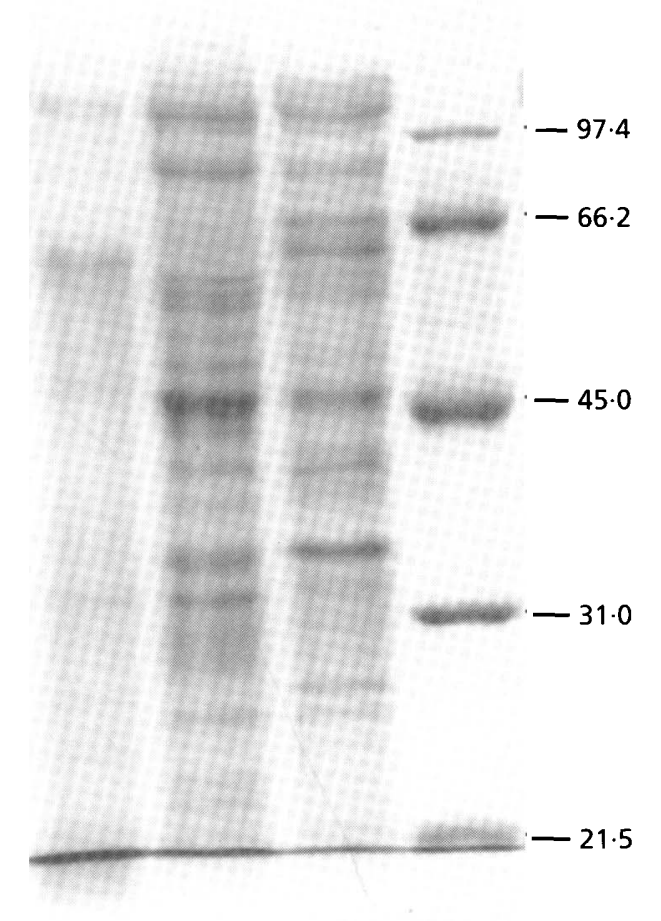

Fig. 1. SDS-PAGE profiles of proteins present in exopolymers produced by Pseudomonas sp. NCIMB 2021 under continuous growth conditions. Lanes: 1, free EPS; 2, biofilm EPS; 3, capsular EPS; 4, molecular-mass markers.

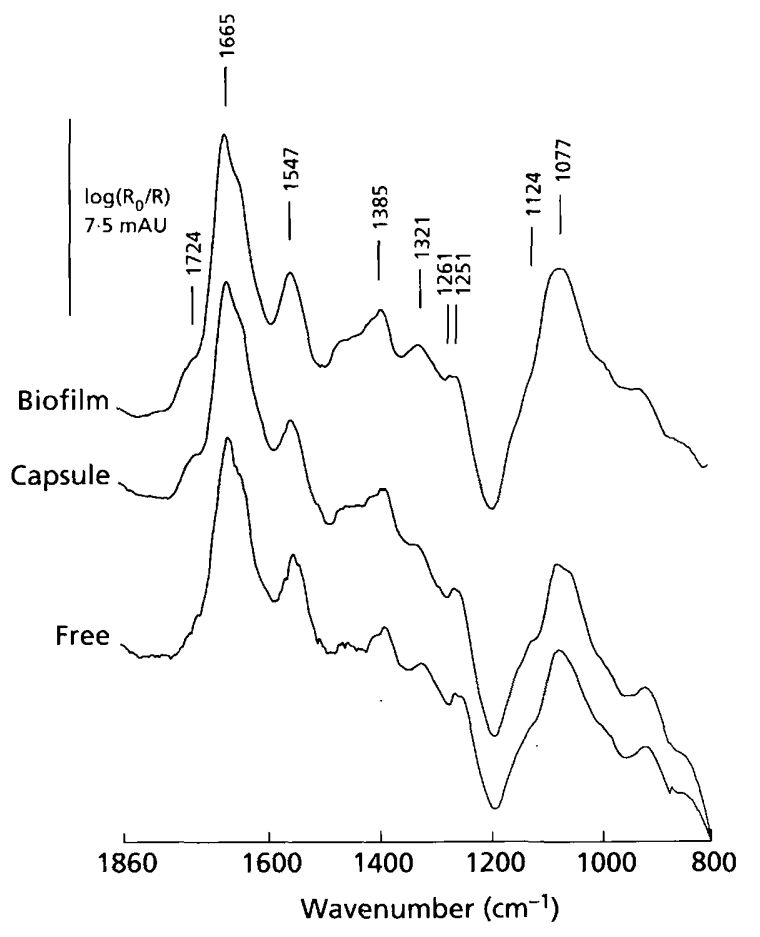

Fig. 2. Reflectance-absorbance FTIR spectra of exopolymers produced by Pseudomonas sp. NCIMB 2021 under continuous growth conditions. The spectra have been vertically displaced for the sake of clarity. AU, absorbance units.

cell size and shape were noted, confirming that the level of contamination of EPS samples due to possible cell lysis would have been insignificant. All harvested EPS were also examined under a light microscope $(\times 100$ objective) and the absence of bacterial cells was confirmed.

Neutral carbohydrate and protein contents of each sample were measured in triplicate (pseudoreplication) and expressed in $\mu \mathrm{g}$ (mg EPS material) $)^{-1}$. Statistical analysis were carried out using a two tailed $t$-test $(P=$ 0.025 ) and analysis of variance (ANOVA) employing MINITAB version 11. A significantly lower neutral sugar content $(P=0.025)$ was recorded in biofilm EPS $\left(11.46 \pm 0.06 \mu \mathrm{g} \mathrm{mg}^{-1}\right)$ compared to the capsular and free EPS $\left(13.32 \pm 0.05\right.$ and $13.35 \pm 0.07 \mu \mathrm{g} \mathrm{mg}^{-1}$, respectively). There was also a significant difference between the protein content of the capsular EPS $(14.14 \pm 0.06 \mu \mathrm{g}$ $\left.\mathrm{mg}^{-1}\right)$ and the biofilm EPS (9.55 $\left.\pm 0.08 \mu \mathrm{g} \mathrm{mg}^{-1}\right)$ as well as the free EPS $\left(9.31 \pm 0.08 \mu \mathrm{g} \mathrm{mg}^{-1}\right)$. Although SDSPAGE showed that the biofilm and capsular EPS shared several common bands, each polymer had its own specific protein profile. Interestingly, fewer distinct protein bands $(100,60$ and $35 \mathrm{kDa})$ were visible against the background in the free EPS (Fig. 1) compared to either the capsule or biofilm EPS.

FTIR spectra (Fig. 2) revealed extensive homology between the samples. Replicate spectra of individual 


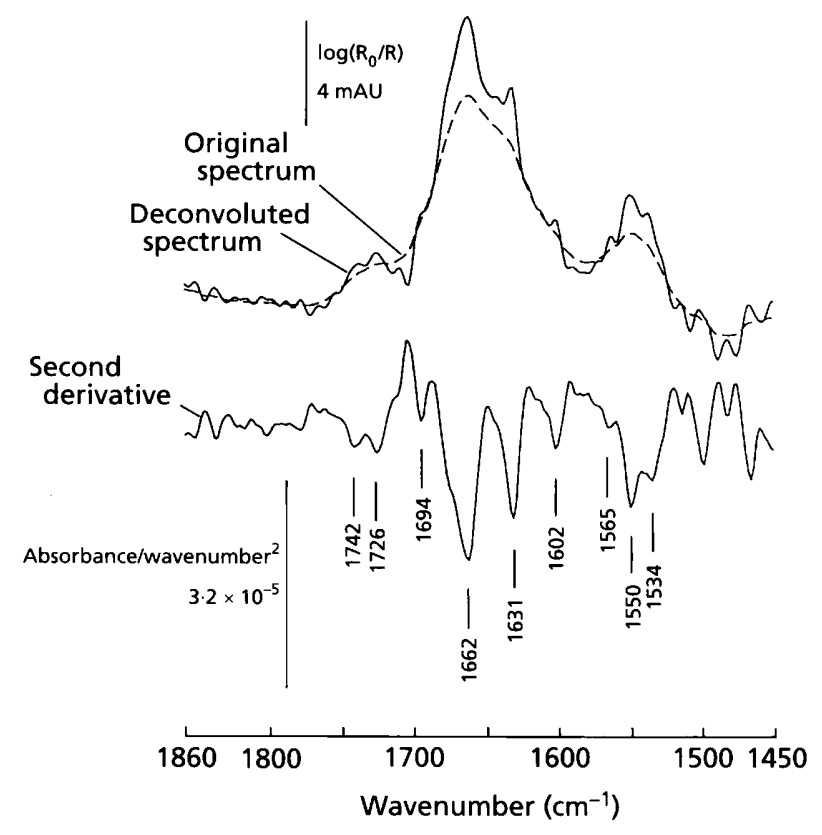

Fig. 3. Reflectance-absorbance FTIR spectrum of the capsular exopolymer of Pseudomonas sp. NCIMB 2021 showing the amide I and amide II regions. The original spectrum (dashed line) is shown together with the deconvoluted (continuous line). The second derivative spectrum is displaced for clarity. $\mathrm{AU}$, absorbance units.

EPS samples demonstrated that differences in absorption were well within the resolution employed. Common to all spectra were vibrations due to the carbohydrate backbone. Strong complex absorptions centred between 1064 and $1078 \mathrm{~cm}^{-1}$ for the three exopolymers are ascribed to complex vibrations of ring structures (including bending, stretching and coupling between these modes; Malfait et al., 1987). Bands between 1200 and $1100 \mathrm{~cm}^{-1}$ are assigned to $\nu \mathrm{C}-\mathrm{C}$ and $\nu \mathrm{C}-\mathrm{O}$ modes, including a shoulder due to the $v_{\mathrm{as}} \mathrm{C}-\mathrm{O}-\mathrm{C}$ of the glycosidic linkage $\left(\sim 1124 \mathrm{~cm}^{-1}\right)$ whilst the main absorption is due to $v \mathrm{C}-\mathrm{O}$ weakly coupled to $\delta \mathrm{C}-\mathrm{O}-\mathrm{H}$ (Malfait et al., 1989). Bands at $1728-1724 \mathrm{~cm}^{-1}$ are due to $\nu \mathrm{C}=\mathrm{O}$ associated with $\mathrm{O}$-acetyl ester bonds. Complex absorptions (not shown for the sake of clarity) at $\sim 2930 \mathrm{~cm}^{-1}$ are ascribed to the asymmetric stretch $\left(v_{\mathrm{as}} \mathrm{C}-\mathrm{H}\right)$ of $-\mathrm{CH}_{2}$ groups combined with that of $-\mathrm{CH}_{3}$ groups. The corresponding symmetric stretches are found at $\sim 2853 \mathrm{~cm}^{-1}$ and $\sim 2877 \mathrm{~cm}^{-1}$, respectively. Absorption bands between 1319 and $1326 \mathrm{~cm}^{-1}$, assigned to the $v \mathrm{C}-\mathrm{O}$ of carboxylic acids, suggested that all three exopolymer were acidic.

Protein-related bands, the $\nu \mathrm{C}=\mathrm{O}$ of the amide I and $\delta \mathrm{NH} / \nu \mathrm{C}=\mathrm{O}$ combination of the amide II bands, were also observable for all three EPS samples. The principal amide I absorption between 1661 and $1665 \mathrm{~cm}^{-1}$ for all three exopolymers suggested a $310^{\text {-helical secondary }}$ structure (Rothschild \& Clark, 1979; Jackson \& Mantsch, 1995). However, the presence of amino sugars, which is manifested by an absorbance band in the same region due to $\mathrm{N}$-acetyl or even glucuronamide $\left(-\mathrm{CONH}_{2}\right)$ groups, cannot be discounted.

Amide II bands were detected at $1547 \mathrm{~cm}^{-1}$. Fourier selfdeconvolution and second derivative spectroscopy of the amide I and II regions, however, indicated the presence of additional bands.

Fig. 3 shows the FTIR spectrum of the capsular exopolymer together with the deconvoluted and smoothed derivative spectra. Band positions obtained from the derivative spectrum were similar for the three exopolymers. However, as will be shown later, the relative 'band intensities' were different for the three exopolymers. A band at $1742 \mathrm{~cm}^{-1}$ is assigned to the

Table 1. Protein secondary structures of exopolymers produced by Pseudomonas sp. NCIMB 2021 in continuous culture as determined by curve-fitting analysis of FTIR spectra

\begin{tabular}{|c|c|c|c|c|c|c|}
\hline \multirow[t]{2}{*}{ Secondary structure } & \multicolumn{2}{|l|}{ Biofilm } & \multicolumn{2}{|l|}{ Capsule } & \multicolumn{2}{|l|}{ Free } \\
\hline & $\begin{array}{l}\text { Wavenumber } \\
\qquad\left(\mathrm{cm}^{-1}\right)\end{array}$ & $\% *$ & $\begin{array}{c}\text { Wavenumber } \\
\left(\mathrm{cm}^{-1}\right)\end{array}$ & $\% *$ & $\begin{array}{c}\text { Wavenumber } \\
\left(\mathrm{cm}^{-1}\right)\end{array}$ & $\% *$ \\
\hline Tyrosine side chain & - & - & 1602 & 1 & 1602 & 1 \\
\hline Aggregated strands & - & - & 1615 & 10 & - & - \\
\hline$\beta$-Sheet & 1631 & 12 & 1631 & 7 & $1627+1632$ & 43 \\
\hline Unordered & $1642+1648$ & 24 & 1642 & 27 & 1641 & 4 \\
\hline $3_{10}$-helix & $1661+1668$ & 42 & 1662 & 29 & $1664+1667$ & 47 \\
\hline $\begin{array}{l}\text { Antiparallel } \beta \text {-sheet } / \\
\text { aggregated strands }\end{array}$ & $1687+1691$ & 22 & $1677+1695$ & 26 & $1682+1695$ & 5 \\
\hline
\end{tabular}

- , None detected.

*Percentage contribution of the absorbance at that wavenumber to the peaks identified in the amide I region. The percentage was calculated using linear combinations of Lorentzian and Gaussian line shapes, fitted using a Levenberg-Marquardt algorithm following baseline correction. 


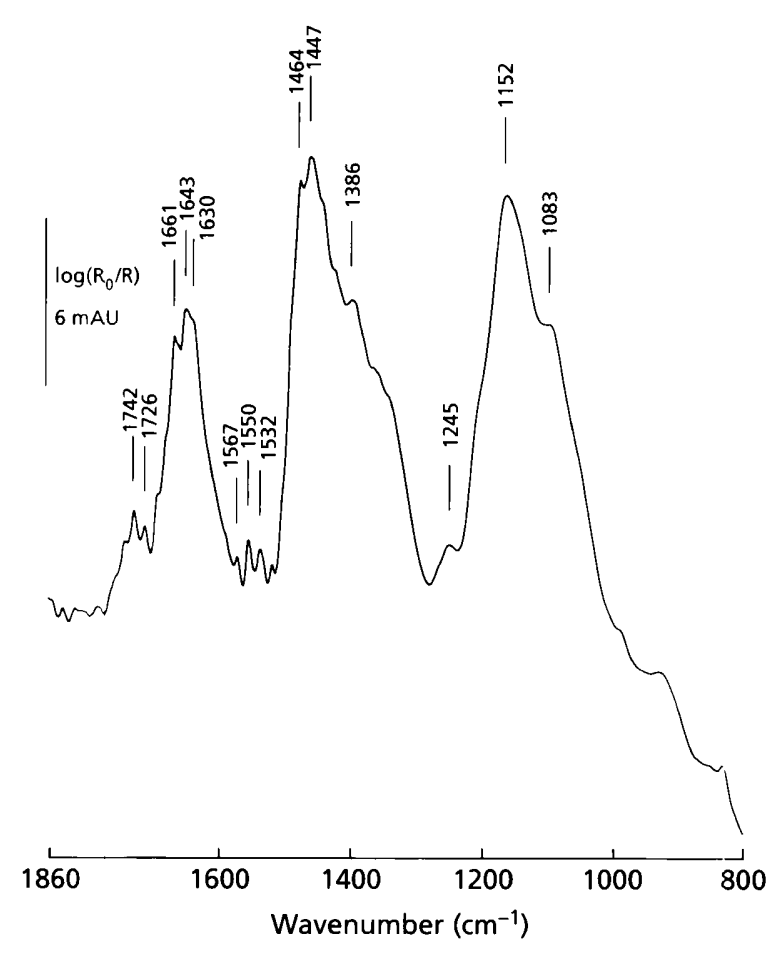

Fig. 4. Reflectance-absorbance FTIR spectrum of the capsular exopolymer of Pseudomonas sp. NCIMB 2021 following H/D exchange. AU, absorbance units.

$\nu \mathrm{C}=\mathrm{O}$ of $\mathrm{O}$-acetyl ester bonds and is accompanied by a doublet at $1262-1251 \mathrm{~cm}^{-1}$ (Fig. 2), including a $v \mathrm{C}$-O absorption at $1251 \mathrm{~cm}^{-1}$ (Sherbrock-Cox et al., 1984). However, the doublet may arise from the amide III $\left(v \mathrm{C}-\mathrm{N}\right.$ and $\left.\delta_{\mathrm{ip}} \mathrm{C}-\mathrm{N}-\mathrm{H}\right)$ of proteins. $\mathrm{N}$-Acetyl ester bonds were also present; the unusually high amide II absorption at $1565 \mathrm{~cm}^{-1}$ has been variously ascribed to either $N$-acetyl (in hyaluronate; Parker, 1983) or $N$ methyl (in N-methylacetamide; Miyazawa et al., 1958) groups. Protein secondary structure was determined by fitting curves to peaks identified in the amide I region (see Jackson \& Mantsch, 1995) and revealed distinct differences between the three exopolymers (Table 1). The principal structure in all three samples was the $\left(3_{10}{ }^{-}\right.$ helix/ $\mathrm{N}$-acetyl or $-\mathrm{CONH}_{2}$ ) peak representing $42 \%$ of the total amide I region of the biofilm EPS, $47 \%$ of the free EPS but only $29 \%$ in the capsular EPS. Whilst the biofilm and capsular EPS contained substantial amounts of unordered structure $(24 \%$ and $27 \%$, respectively), the free EPS contained considerably less $(4 \%)$. In contrast, parallel $\beta$-sheet structures represented $43 \%$ in the free EPS but only $12 \%$ and $7 \%$ in the biofilm and capsular EPS, respectively.

The FTIR spectrum after H/D exchange confirmed the presence of absorption bands at 1742, 1726 and $1567 \mathrm{~cm}^{-1}$ due to unexchanged $\mathrm{O}$ - and $\mathrm{N}$-acetyl groups (Fig. 4). The principal amide I peak at $1661 \mathrm{~cm}^{-1}$ remained (further emphasizing the possibility of $-\mathrm{CONH}_{2}$ groups being present), together with some residual amide II absorption at 1550 and $1532 \mathrm{~cm}^{-1}$. Amide $\mathrm{I}^{\prime}$ and II' $^{\prime}$ absorptions were identified at 1643$1630 \mathrm{~cm}^{-1}$ and $1464-1447 \mathrm{~cm}^{-1}$, respectively. It is interesting to note that the doublet associated with either the $v \mathrm{C}-\mathrm{O}$ of $\mathrm{O}$-acetyl ester bonds or the $v \mathrm{C}-$ $\mathrm{N} / \delta \mathrm{C}-\mathrm{N}-\mathrm{H}$ modes at 1261 and $1251 \mathrm{~cm}^{-1}$ for the $\mathrm{H}$ spectra (prior to $\mathrm{H} / \mathrm{D}$ exchange, Fig. 2) was replaced by a single peak in the D spectra (after H/D exchange, Fig. 4). Hence, the $1261 \mathrm{~cm}^{-1}$ absorption was due to amide III, whilst the $1251 \mathrm{~cm}^{-1}$ was indeed due to the acetyl group. However, no new absorption at $1040-940 \mathrm{~cm}^{-1}$ due to $\delta \mathrm{N}-\mathrm{D}$ of amide III' $^{\prime}$ was observed in the $\mathrm{D}$ spectra.

The relative uronic acid content, together with the extent of acylation, was estimated as a proportion of the total carbohydrate content of the EPS. This was achieved by calculating the ratios of integrated peak areas $\mathrm{A}$, from the spectra of peaks at $1319-1326 \mathrm{~cm}^{-1}(\nu \mathrm{C}-\mathrm{O}$, carboxylic acids, A1), $1728-1724 \mathrm{~cm}^{-1}(\nu \mathrm{C}=\mathrm{O}, \mathrm{O}-$ acetyl ester bonds, A2), and $1565 \mathrm{~cm}^{-1}$ ( $N$-acetyl ester bonds, A3), with the peak centred between 1064 and $1077 \mathrm{~cm}^{-1}$ due to the carbohydrate backbone (A4). The biofilm and free EPS contained roughly equivalent levels of uronic acid residues (relative to carbohydrate content) with A1:A4 ratios of $0 \cdot 102$ and $0 \cdot 084$, respectively, whilst the capsular EPS A1: A4 ratio was only $0 \cdot 044$. The greatest degree of $\mathrm{O}$ - and $\mathrm{N}$-acylation was found in the biofilm EPS with A2: A4 and A3: A 4 ratios of 0.011 and 0.014 , respectively, compared to 0.006 and 0.003 , respectively, for the capsular EPS, and 0.003 and 0.000 , respectively, for the free EPS.

\section{DISCUSSION}

The distinction between capsular and slime exopolymers is an imprecise one, the latter often attributed either to overproduction of a tightly bound (to the cell wall) capsular polymer or to insufficient binding of the polymers to the wall (Beveridge \& Graham, 1991; Fletcher \& Floodgate, 1973). Although the assumption is that the two polymers are chemically identical and that it is only in their position relative to the cell that differences are observed, chemical differences between capsular and 'slime' exopolymers have been reported, for example, in Rhodopseudomonas capsulata Sp11 (Omar et al., 1983).

By collecting exopolymers from the culture medium (free EPS), planktonic phase (capsular EPS) and adhered cells (EPS associated with a biofilm; i.e. slime), we were able to qualitatively characterize these exopolymers using SDS-PAGE and FTIR spectroscopy. The data showed that the three polymers shared certain features, in agreement with published data. For example, all were carbohydrate/protein co-polymers, with the carbohydrate moieties being both acidic (Fletcher \& Floodgate, 1973) and O-acetylated (Christensen, 1989).

Reported protein contents of bacterial exopolymers range between 1 and 18\% (Abu et al., 1991; Robijn et al., 1995; Guezennec et al., 1994; Vincent et al., 1994) 
and for Pseudomonas sp. NCIMB 2021 varies depending upon the type of EPS. FTIR spectroscopic analysis demonstrated that the predominant protein secondary structure of all three EPS types is a $310^{\text {-helix (although }}$ there could be some confusion with amino sugars; see above), which, moreover, is resistant to $H / D$ exchange. SDS-PAGE profiles demonstrated differences in protein composition between biofilm, capsular and free EPS (Fig. 1) while FTIR spectroscopy revealed differences in overall protein secondary structure (Table 1). The capsular EPS protein moiety displayed a considerably reduced $3{ }_{10}$-helical component and an increased aggregated strand component compared to the biofilm EPS, whilst the free EPS protein displayed a marked increase in $\beta$-sheeting and a reduced unordered component. Since an equal amount of protein, as estimated using the Bradford (1976) assay, was present in each EPS sample loaded onto the gel, it is apparent that each polymer has its own specific profile. This strongly indicates differences in the protein composition between EPS samples. The most obvious difference was noted for the free exopolymer released into the bulk phase of the Pseudomonas NCIMB 2021 culture. The smeary appearance of the gel and the presence of only few distinct bands in the free EPS indicated that proteins in this sample were degraded to produce different length polypeptides. Indeed, the free EPS protein profile (lane 1) extended beyond the dye front. The observed degradation is most likely due to the action of the non-specific proteases which would be present in the bulk phase.

Exopolymer production by Pseudomonas sp. NCIMB 2021 is therefore similar to exopolymer production by $P$. aeruginosa, if somewhat more subtle. Attachment of $P$. aeruginosa is associated with up-regulation of $\operatorname{algC}$ and algD promoters (Davies et al., 1993; Hoyle et al., 1993) (similar to the up-regulation of the lacZ marker gene in attachment studies using Pseudomonas S9; Dagostino et al., 1991), resulting in alginate production. Christensen et al. (1985) demonstrated the presence of $\mathrm{N}$-acetylglucosamine and 6-deoxyhexoses in exopolymers produced in the late stationary phase in batch culture which were not present in exopolymers produced by cells in growth phase. Protein profiles also appear to differ between biofilm and planktonic cells (Costerton et al., 1995). Phenotypic differences arising from cell attachment in Pseudomonas sp. NCIMB 2021, did not result in the production of completely novel EPS. This is in contrast to $P$. aeruginosa, which was characterized by low exopolymer production (Christensen et al., 1985). However, we have demonstrated that ratios between carbohydrate residues, the degree of polysaccharide acetylation and the profiles and secondary structure of the protein moiety were dependent upon the cellular mode of growth.

\section{ACKNOWLEDGEMENTS}

The authors gratefully acknowledge financial support by the NERC (GST/02/1445 and GST/02/1440) as part of the Marine Biofouling Thematic programme.

\section{REFERENCES}

Abu, G. O., Weiner, R. M., Rice, J. \& Colwell, R. R. (1991). Properties of an extracellular adhesive polymer from the marine bacterium Shewanella colwelliana. Biofouling 3, 69-84.

Allison, D. G. \& Sutherland, I. W. (1987). The role of exopolysaccharides in adhesion of freshwater bacteria. J Gen Microbiol 133, 1319-1327.

Allison, D. G., Brown, M. R. W. \& Gilbert, P. (1991). Slow adherent growth modulates polysaccharide production by Pseudomonas aeruginosa. Biofouling 4, 243.

Beveridge, T. J. \& Graham, L. L. (1991). Surface layers of bacteria. Microbiol Rev 55, 684-705.

Bradford, M. M. (1976). A rapid and sensitive method for the quantitation of microgram quantities of protein utilizing the principle of protein-dye binding. Anal Biochem 72, 248-254.

Chaplin, M. F. \& Kennedy, J. F. (1986). Carbohydrate Analysis: a Practical Approach. Oxford: IRL Press.

Christensen, B. E. (1989). The role of extracellular polysaccharides in biofilms. J Biotechnol 10, 181-202.

Christensen, B. E., Kjosbakken, J. \& Smidsrød, O. (1985). Partial chemical and physical characterisation of two extra-cellular polysaccharides produced by a marine, periphytic Pseudomonas sp. strain NCMB 2021. Appl Environ Microbiol 50, 837-844.

Costerton, J. W., Lewandowski, Z., Caldwell, D. E., Korber, D. R. \& Lappin-Scott, H. (1995). Microbial biofilms. Annu Rev Microbiol 49, 711-745.

Dagostino, L., Goodman, A. E. \& Marshall, K. C. (1991). Physiological responses induced in bacteria adhering to surfaces. Biofouling 4, 113-119.

Davies, D. G., Chakrabarty, A. M. \& Geesey, G. G. (1993). Exopolysaccharide production in biofilms: substratum activation of alginate gene expression by Pseudomonas aeruginosa. Appl Environ Microbiol 59, 1181-1186.

Deretic, V., Schurr, M. J., Boucher, J. C. \& Martin, D. W. (1994) Conversion of Pseudomonas aeruginosa to mucoidy in cystic fibrosis: environmental stress and regulation of bacterial virulence by alternative sigma factors. J Bacteriol 176, 2773-2780.

Dzandu, J. K., Deh, M. E., Barratt, D. L. \& Wise, G. E. (1984). Detection of erythrocyte membrane proteins, sialoglycoproteins, and lipids in the same polyacrylamide gel using a double-staining technique. Proc Natl Acad Sci USA 81, 1733-1737.

Fletcher, M. \& Floodgate, G. D. (1973). An electron-microscopic demonstration of an acidic polysaccharide involved in the adhesion of a marine bacterium to solid surfaces. J Gen Microbiol 74, 325-334.

Geesey, G. G., Mutch, R., Costerton, J. W. \& Green, R. B. (1978). Sessile bacteria: an important component of the microbial population in small mountain streams. Limnol Oceanogr 23, 1214-1223.

Guezennec, J. G., Pignet, P., Raguenes, G., Deslandes, E., Lijour, Y. \& Gentric, E. (1994). Preliminary chemical characterization of unusual eubacterial exopolysaccharides of deep-sea origin. Carbohydr Res 24, 287-294.

Hernandez, R. M. \& Kalaji, M. (1996). Use of isotopically labelled compounds for the in situ IR study of the electroreduction of $\mathrm{CO}$. in aqueous hydrogencarbonate and buffered phosphate solutions. J Chem Soc Faraday Trans 92, 3957-3962.

Hoyle, B. D., Williams, L. J. \& Costerton, J. W. (1993). Production of mucoid exopolysaccharides during development of Pseudomonas aeruginosa biofilms. Infect Immun 58, 2383-2385.

Jackson, M. \& Mantsch, H. H. (1995). The use and misuse of FTIR 
spectroscopy in the determination of protein secondary structure. Crit R' Biochem Mol Biol 30, 95-120.

Kossovsky, N., Nguyen, A., Sukiassians, K., Festekjian, A., Gelman, A. \& Sponsler, E. (1994). Secondary structure of albumin acquired rapidly by modified conventional ATR-FTIR is comparable to CD spectral data. J Colloid Interface Sci 166, 350-355.

Laemmli, U. K. (1970). Cleavage of structural proteins during the assembly of the head of bacteriophage T4. Nature 227, 680-685.

Malfait, T., van Dael, H. \& van Cauwelaert, F. (1987). Raman spectroscopic analysis of the sodium salt of kappa-carrageenan and related compounds in solution. Carbohydr Res 163, 9-14.

Malfait, T., van Dael, H. \& van Cauwelaert, F. (1989). Molecular structure of carrageenans and kappa oligomers-a Raman spectroscopic study. Int J Biol Macromol 11, 259-264.

Martin, D. W., Schurr, M. J., Yu, H. \& Deretic, V. (1994). Analysis of promoters controlled by the putative sigma factor algU regulating conversion to mucoidy in Pseudomonas aeruginosa: relationship to $\sigma^{\mathrm{E}}$ and stress response. J Bacteriol 176, 6688-6696.

Miyazawa, T., Shimanouchi, T. \& Mizushima, S.-I. (1958). Normal vibrations of $N$-methylacetamide. J Chem Phys 29, 611-616.

Neu, T. R. \& Marshall, K. C. (1991). Microbial 'footprints' - a new approach to adhesive polymers. Biofouling 3, 101-112.

Omar, A. S., Weckesser, J. \& Mayer, H. (1983). Different polysaccharides in the external layers (capsule and slime) of the cell envelope of Rhodopseudomonas capsulata $\mathrm{Sp11.} \mathrm{Arch} \mathrm{Microbiol}$ 136, 291-296.

Parker, F. S. (1983). Applications of Infrared, Raman, and Resonance Raman Spectroscopy in Biochemistry. New York: Plenum.

Rahmelow, K. \& Hübner, W. (1996). Fourier self-deconvolution: parameter determination and analytical band shapes. Appl Spectrosc 50, 795-804.

Robijn, G. W., van den Berg, D. J. C., Haas, H., Kamerling, J. P. \& Vliegenhart, J. F. G. (1995). Determination of the structure of the exopolysaccharide produced by Lactobacillus sake 0-1. Carbohydr Res 276, 117-136.

Rothschild, K. J. \& Clark, N. A. (1979). Anomalous amide I infrared absorption of purple membrane. Science 204, 311-312.

Savitzky, A. \& Golay, J. E. (1964). Smoothing and differentiation of data by simplified least squares procedures. Anal Chem 36, $1627-1639$.

Sherbrock-Cox, V., Russell, N. J. \& Gacesa, P. (1984). The purification and chemical characterisation of the alginate present in extracellular material produced by mucoid strains of Pseudomonas aeruginosa. Carbobydr Res 135, 147-154.

Tapper, R. (1998). The use of biocides for the control of marine biofilms. PhD thesis, University of Portsmouth.

Vandevivere, P. \& Kirchman, D. L. (1993). Attachment stimulates exopolysaccharide synthesis by a bacterium. Appl Environ Microbiol 59, 3280-3286.

Vincent, P., Pignet, P., Talmont, F., Bozzi, L., Fournet, B., Guezennec, J., Jeanthon, C. \& Prieur, D. (1994). Production and characterization of an exopolysaccharide excreted by a deep-sea hydrothermal vent bacterium isolated from the polychaete Alvinella pompejana. Appl Environ Microbiol 60, 4134-4141.

Williams, A. G. \& Wimpenny, J. W. T. (1977). Exopolysaccharide production by Pseudomonas NCIB 11264 grown in batch culture. J Gen Microbiol 102, 13-21.

Received 21 September 1998; revised 25 January 1999; accepted 8 February 1999 